\title{
Vertical Profiles of Ozone Concentration Collected by an Unmanned Aerial Vehicle and the Mixing of the Nighttime Boundary Layer over an Amazonian Urban Area
}

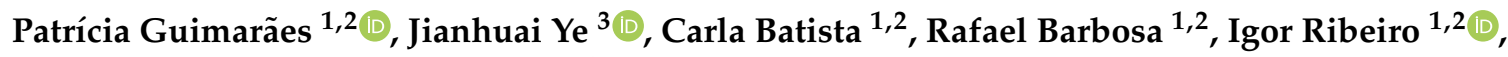 \\ Adan Medeiros ${ }^{2}$, Rodrigo Souza ${ }^{2, *}$ and and T. Martin ${ }^{3,4, *}$ \\ 1 Post-Graduate Program in Climate and Environment, National Institute of Amazonian Research and \\ Amazonas State University, Manaus, Amazonas 69060-001, Brazil; guimaraespc.uea@gmail.com (P.G.); \\ cestefanibatista@gmail.com (C.B.); rgb.barbosa@gmail.com (R.B.); igorgeoinformacao@gmail.com (I.R.) \\ 2 School of Technology, Amazonas State University, Manaus, Amazonas 69065-020, Brazil; \\ amedeiros@uea.edu.br \\ 3 School of Engineering and Applied Sciences, Harvard University, Cambridge, MA 02138, USA; \\ jye@seas.harvard.edu \\ 4 Department of Earth and Planetary Sciences, Harvard University, Cambridge, MA 02138, USA \\ * Correspondence: souzaraf@gmail.com (R.S.); scot_martin@harvard.edu (S.T.M.); \\ Tel.: +55-92-98815-2749 (R.S.); +1-617-495-0627 (S.T.M.)
}

Received: 20 August 2019; Accepted: 30 September 2019; Published: 3 October 2019

Abstract: The nighttime boundary layer was studied in an urban area surrounded by tropical forest by use of a copter-type unmanned aerial vehicle (UAV) in central Amazonia during the wet season. Fifty-seven vertical profiles of ozone concentration, potential temperature, and specific humidity were collected from surface to $500 \mathrm{~m}$ above ground level (a.g.1.) at high vertical and temporal resolutions by use of embedded sensors on the UAV. Abrupt changes in ozone concentration with altitude served as a proxy of nighttime boundary layer (NBL) height for the case of a normal, undisturbed, stratified nighttime atmosphere, corresponding to $40 \%$ of the cases. The median height of the boundary layer was $300 \mathrm{~m}$. A turbulent mixing NBL constituted $28 \%$ of the profiles, while the median height of the boundary layer was $290 \mathrm{~m}$. The remaining 32\% of profiles corresponded to complex atmospheres without clear boundary layer heights. The occurrence of the three different cases correlated well with relative cloud cover. The results show that the standard nighttime model widely implemented in chemical transport models holds just $40 \%$ of the time, suggesting new challenges in modeling of regional nighttime chemistry. The boundary layer heights were also somewhat higher than observed previously over forested and pasture areas in Amazonia, indicating the important effect of the urban heat island.

Keywords: ozone; Amazonia; UAV; boundary layer

\section{Introduction}

The nighttime boundary layer (NBL) occurs in response to surface cooling associated with the emission of long-wave radiation into space, causing a temperature inversion in the overlying atmospheric column at a maximum vertical extent of about $500 \mathrm{~m}$ [1]. For this atmospheric structure in its theoretical state, conditions of atmospheric stability result, and there is little or no vertical mixing between the surface layer and the altitudes above the NBL [1]. The atmosphere is described as a normal, undisturbed, stratified nighttime atmosphere. Turbulence is typically considered weak and sporadic, and the time scale of mixing in this layer is taken as several hours [2]. Compared to this 
theoretical description, there are suggestions of intermittent turbulence associated with overhead jets [3], gravitational wave breaking [4], or baroclinicity [5]. These processes can influence the structure and development of the NBL, including vertical mixing processes across the NBL [6-8]. Moreover, in urban regions, the effects of a heat island, meaning an elevated surface temperature relative to adjacent non-urban regions, can also further affect the development of the NBL [9].

The mechanisms associated with possible NBL mixing can be complex [10]. Thermal and mechanical instabilities, caused by the horizontal and vertical propagation of gravity waves, can initiate sporadic or intermittent turbulent mixing [11-16]. Furthermore, in the presence of strong thermal stratification, the mechanical wind shear near the top of the thermal inversion can lead to the formation of low-level jets, which in turn can induce turbulence and increase mixing [17-19]. Finally, events associated with descending currents of air during convective storms can penetrate into the NBL and induce complete air exchange [20,21]. Given the complexity of these various processes cited above, all of which may be further influenced by the urban heat island, vertical transport in the NBL remains incompletely understood [22-24].

Approaches used to collect atmospheric data to characterize the NBL include radiosondes on tethered balloons, remote sensing aboard airplanes or from the surface, and instrumented meteorological towers. Each approach has varying capabilities and limitations with respect to the temporal and spatial resolution of atmospheric data collection. They are also differentiated by cost and differing logistics requirements. Seibert et al. [25] provided a comparative review, albeit without reference to unmanned aerial vehicles (UAVs) which were unavailable at that time. Copter-type UAVs recently became available at mid-level pricing and relatively quick user training, meaning that UAVs are increasingly becoming part of the portfolio of atmospheric scientists. Most relevant for comparison to copter-type UAVs for in situ measurements are radiosondes and tethered balloons (Table S4, Supplementary Materials). Radiosondes have high ascent rates and, thus, very quickly cross the boundary layer, allowing the collection of relatively few data points. Their position also drifts horizontally with the prevailing winds, and the collected datasets, thus, do not represent a purely vertical column measurement. Approximately 50 data points of $2 \mathrm{~s}$ each spaced by $10 \mathrm{~m}$ in the vertical from 0 to $500 \mathrm{~m}$ can be considered representative. Tethered balloons have a controlled ascent rate, but they are expensive and logistically complicated to control. Approximately 25 data points of $10 \mathrm{~s}$ each spaced by $20 \mathrm{~m}$ can be considered a representative dataset from 0 to $500 \mathrm{~m}$. Mid-level copter-type UAVs used increasingly in scientific deployments can be described as collecting 100 data points of $10 \mathrm{~s}$ each spaced by $5 \mathrm{~m}$ in the vertical from 0 to $500 \mathrm{~m}$ at relatively low cost. This emerging approach for in situ measurements thus complements the traditional approaches by offering improvements in the vertical and temporal resolutions of measurements.

One of the pioneering studies on the characteristics of the Amazonian NBL was carried out by Fisch [26], followed by other robust studies in different seasons by Santos [10] and Neves et al. [16]. In these previous studies, vertical profiles of potential temperature and specific humidity were the main observations used to estimate the NBL height $[16,27]$. However, for cloudy and partly cloudy conditions, the use of these profiles to infer the NBL height often yielded ambiguous results because of small differences (i.e., below sensor precision) between the surface values and the top of the boundary layer for temperature and humidity [28]. Nighttime cloudiness is common to various degrees over the tropical forest because of the strong water emissions by forest evapotranspiration under warm conditions [29]. Despite these difficulties, vertical profiles of potential temperature and specific humidity are broadly used for all-sky conditions because of the wide availability of inexpensive sensors, the ease of data analysis, and the strong theoretical underpinning between the vertical profiles and the boundary layer height [30].

As an alternative to potential temperature and specific humidity over forests, chemical tracers might better define the NBL structure. Pal et al. [31] compared the boundary layer with a "volume of the box," where the mixing and dispersion of various chemical compounds take place. Chemical tracers like ozone, carbon dioxide, methane, nitrogen oxides, aerosol particles, and radioactive noble gas radon 
$\left({ }^{222} \mathrm{Rn}\right)$, among others, might provide significant information on the NBL structure depending on local conditions [31-37]. For this purpose, local criteria include a chemical species whose concentration close to the surface is relatively low (which is typically related to a reactive sink there with vegetation or chemical reactions) and whose concentration is comparatively high in the mixed atmosphere above the NBL.

Over the tropical forest in central Amazonia, ozone satisfies the necessary criteria [38]. Ozone is produced in the daytime troposphere from photochemical reactions among natural and anthropogenic precursors that include industrial, vehicle, and biosphere emissions [38,39]. At nighttime, production ceases, and the residual daytime concentration remains in what is effectively a well-mixed infinite reservoir overlying the relatively thin NBL $[6,40,41]$. At the surface, there is a strong ozone sink through both stomatal and non-stomatal processes [21,42,43]. Stomatal uptake occurs via dry deposition when ozone meets specific locations of the plants along the path from outside the leaf to the reaction site inside the apoplast [44]. The uptake rate of the stomatal pathway varies among plant species, genotype, plant phenology, leaf age, position in the canopy, and nutrient availability [45-49]. Non-stomatal processes involve ozone deposition to soil, stems, and cuticles, along with chemical losses such as reactions with nitric oxide (NO) in the atmosphere in polluted environments [48]. The strong ozone sink at the surface owing to reactive dry deposition or chemical losses leads to the expectation of a step function in ozone concentration across the top of the NBL for nighttime atmosphere $[8,9,33-35]$. Such a profile is suggested as a method in this study to infer the NBL height.

The study described herein focuses on the NBL of urban Manaus, an environment little explored in previous studies in the Amazon. This environment deserves attention due to the heat island configuration that may imply NBL height differences compared to previous studies on forest and pasture regions (Table S1, Supplementary Materials). In addition, the results of this study highlight that ozone can be used as a tracer to probe the dynamics of the NBL. This approach adds valuable information on the NBL height that supplements traditional measurements from potential temperature and specific humidity when the weather conditions and other factors are not favorable to their use. The primary dataset of this study consists of vertical profiles of ozone concentration, potential temperature, and specific humidity, allowing a comparative assessment among these metrics. A copter-type unmanned aerial vehicle was used in conjunction with a sensing system to collect the vertical profiles. The knowledge generated in this study can contribute to the improvement of atmospheric chemistry and air quality models, especially for tropical urban environments where ozone concentrations can affect the health and well-being of the population [50,51].

\section{Methodology}

\subsection{Location}

Manaus, Brazil, is located at the confluence of two large rivers, Rio Negro and Rio Solimões, in the forested Amazon Basin. It has a population of over two million and covers an area of $11.4 \times 10^{6} \mathrm{~km}^{2}$ [52]. The climatology of the accumulated precipitation and annual and monthly temperature of Manaus are around $2307.4 \mathrm{~mm} \cdot \mathrm{yr}^{-1}$ and $26.7^{\circ} \mathrm{C}$, respectively [53]. The UAV flights were carried out on the campus of the School of Technology, Amazonas State University (3.0918 south (S), $60.0175^{\circ}$ west (W)), in the central region of the city. The campus is surrounded by urbanized residential and commercial areas interspersed by forested areas (Figure 1). A view of local land cover around the flight location is also shown in Figure 1. There was a forested region directly around the launch site, which transitioned into urban residential and commercial areas. The maximum infrastructure height was $65 \mathrm{~m}$ in the radius of $500 \mathrm{~m}$ from the UAV launch site. Although no ground-level continuous ozone monitoring was conducted during the sampling period, ozone concentrations range from 0 to $40 \mathrm{ppbv}$ in the wet season in urban Manaus. The highest concentrations occur around noon, and the lowest concentrations are at night. 


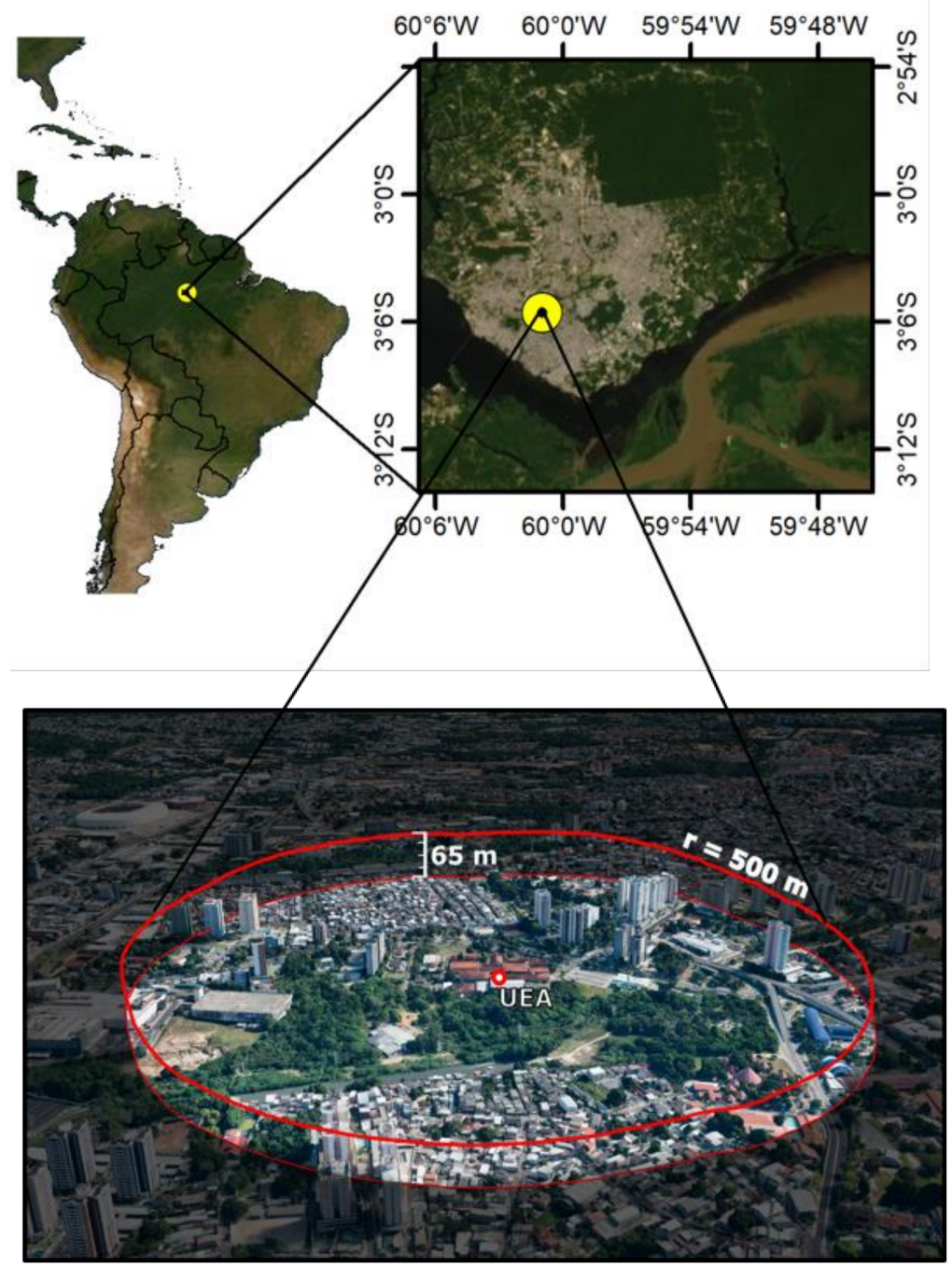

Figure 1. (top) Satellite image of the study area for the city of Manaus in central Amazonia, Brazil. The urban region (white), the interspersed and surrounding forest (green), and the south and northwest rivers (brown and black, respectively) are apparent (ESRI aerial imagery basemap, 2019). Night flights to collect vertical profiles were based on the campus of the Amazonas State University (UEA) (yellow circle; UEA pin). (bottom) Depiction of the urban canopy around the study area (UEA pin). The maximum infrastructure height is $65 \mathrm{~m}$ in the radius of $500 \mathrm{~m}$ from the unmanned aerial vehicle (UAV) launch site. As seen in the image, there is a forested region directly around the launch site that transitions into an urban residential and commercial area. The image was produced by Google Earth $3 \mathrm{D}$, and the orientation is due north.

\subsection{Flight Platform and Instrumentation}

A hexacopter unmanned aerial vehicle (DJI Matrice 600 model) was used. It had a maximum flight time of $35 \mathrm{~min}$ and a maximum take-off weight of $15 \mathrm{~kg}$, allowing for up to a 5-kg payload. The maximum speed of ascent was $5 \mathrm{~m} \cdot \mathrm{s}^{-1}$ and that of descent was $3 \mathrm{~m} \cdot \mathrm{s}^{-1}$. The upper altitude was limited to $500 \mathrm{~m}$ above ground level by geofencing from the manufacturer. Standard equipment of the DJI flight package recorded telemetry of latitude, longitude, and altitude by use of a global positioning system (GPS).

A commercially available ozone sensor based on ultraviolet absorption (Personal Ozone Monitor, POM; 2B Technologies Inc., Boulder, CO, USA) was mounted to the top platform of the UAV. The precision of the measurements $(1 \sigma)$ was the greater of either $1.5 \mathrm{ppbv}$ or $2 \%$ of reading. The minimum limit of detection was 3 ppbv. The instrument recorded pressure, as well as GPS latitude, longitude, and 
altitude. The instrument was calibrated weekly by a Model 306 ozone calibrator (2B Technologies Inc.) (Figure S5, Supplementary Materials). Ozone measurements were made every $10 \mathrm{~s}$ at a sampling flow rate of $0.75 \mathrm{~L} \cdot \mathrm{min}^{-1}$. Measurements were binned and averaged across vertical intervals of $15 \mathrm{~m}$ from the surface up to $500 \mathrm{~m}$ in height.

Temperature and relative humidity $(\mathrm{RH})$ along the vertical profiles were recorded by standard sensors (Hobo Model U10-003, Onset Computer Corporation, Bourne, MA, USA). For temperature and RH measurement, the precisions were $\pm 0.35{ }^{\circ} \mathrm{C}$ from $0{ }^{\circ} \mathrm{C}$ to $50{ }^{\circ} \mathrm{C}$, and $\pm 2.5 \%$ from $10 \%$ to $90 \% \mathrm{RH}$, respectively. Both meteorological measurements were recorded every $10 \mathrm{~s}$. For the meteorological profiles, the potential temperature and specific humidity were calculated, interpolated every $15 \mathrm{~m}$ to match the analysis of ozone concentrations. At $3 \mathrm{~m}$ above the surface but not onboard the UAV, wind velocity was also measured (Wind Monitor Sensor Model 05103-5A, R.M. Young Company, Michigan, MI, USA). The sensor measured wind speed from $0-100 \mathrm{~m} \cdot \mathrm{s}^{-1}$ at an accuracy of $\pm 0.3 \mathrm{~m} \cdot \mathrm{s}^{-1}$ and wind direction at an accuracy of $\pm 3^{\circ}$.

\subsection{UAV Flights}

UAV flights took place during the wet season from 30 March 2018 to 11 May 2018. There were 57 flights on nine different weekdays (Table S2, Supplementary Materials). There were typically eight flights per night at 30-min intervals from 20:00 to 00:00 (local time, LT). Local time was $4 \mathrm{~h}$ earlier than coordinated universal time (UTC). On some nights, there were fewer than eight flights because of unforeseen events, such as the rapid formation of clouds suggesting the possibility of precipitation that could compromise the instruments or the UAV. For data collection, an ascent speed of $0.5 \mathrm{~m} \cdot \mathrm{s}^{-1}$ was used, and 57 profiles were collected. A summary of flights is listed in Table S2 (Supplementary Materials). The flight patterns and flight permissions followed the regulations of the Brazilian National Civil Aviation Agency and associated agencies (RBAC-E No. 94/2017) [54]. The Brazilian Department of Airspace Control closed the airspace to others and authorized flights over the campus of Amazonas State University up to $500 \mathrm{~m}$ in height during the flight periods.

\subsection{Data Analysis}

The NBL height was determined based on the profile method. The vertical profile of ozone concentration has a steep slope at the boundary layer top [1]. The atmospheric layer across which a clear inversion occurs in concentration can be used to estimate the NBL height where the profile changes rapidly with height across at least three consecutive altitude points. The lowest point of this layer is taken as the height of the boundary layer [10,55]. For comparison, methods used in other studies to determine the NBL height can include the profile method, the bulk Richardson number, mean wind speed, mean potential temperature, the gradient method, variance analysis, continuous wavelet transforms, and fitting idealized profiles $[1,56]$.

There are three cases of profiles observed in this study. A normal, undisturbed, stratified nighttime atmosphere is referred to as "case 1", representing the theoretical NBL profile of a step function. "Case 2" represents a turbulently mixing NBL with a smooth increase of ozone concentration from surface to NBL top. Other profiles with complex characteristics of both stratified and turbulent atmospheres are classified as "case 3", in which NBL heights cannot be estimated through the profiles of the tracers. For the weather conditions, the profiles were classified into three categories based on the hourly observation of each flight as clear, partly cloudy, and cloudy skies. Based on the case classification of the observed profiles, a statistical analysis using Cramer's V was carried out between nominal variables of stratified, turbulent, and complex structures in the NBL (i.e., cases 1, 2, and 3 of the analysis herein) and nominal variables of clear, partly cloudy, and cloudy skies [57]. In addition, estimates of the NBL height obtained by the Global Data Assimilation System (GDAS), through the Real-time Environmental Applications and Display (READY) platform, for the city of Manaus, were also used to compare with the NBL height results of the UAV-observed profiles $[58,59]$. 


\section{Results and Discussion}

Fifty-seven vertical profiles of ozone concentration, potential temperature, and specific humidity were collected (Figure S1, Supplementary Materials). An example of one dataset representative of many profiles ( $40 \%$ of total) is plotted in Figure 2. For this profile, in an abrupt shift, the ozone concentration changed by more than $15 \mathrm{ppbv}$ across the altitude range of 150 to $200 \mathrm{~m}$, representing the top of the NBL. For comparison, the change in potential temperature across the profile from surface to $500 \mathrm{~m}$ was $1 \mathrm{~K}$, and the top of the NBL was not clearly discernable with this sensor. Specific humidity changed by $1 \mathrm{~g} \cdot \mathrm{kg}^{-1}$ and had an inflection point at a similar altitude to that of the shift in ozone concentration. Even so, the inflection point was weak, and, as a standalone dataset in the absence of the ozone dataset, the height of the top of the NBL would not be clear. Thus, in this example, ozone concentration represents the conclusive dataset, specific humidity is a supportive dataset, and potential temperature is not informative. Profiles of the type represented in Figure 2 correspond to a normal, undisturbed, stratified nighttime atmosphere, and they are referred to as "case 1" in the analysis herein, representing the theoretical NBL profile of a step function anticipated by Stull [1].

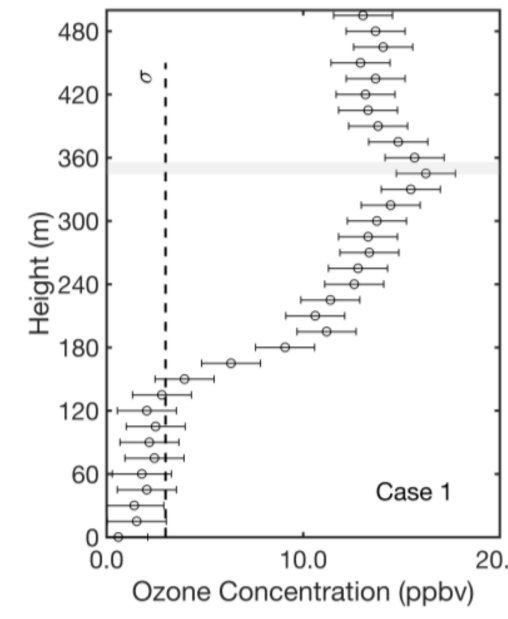

(a)

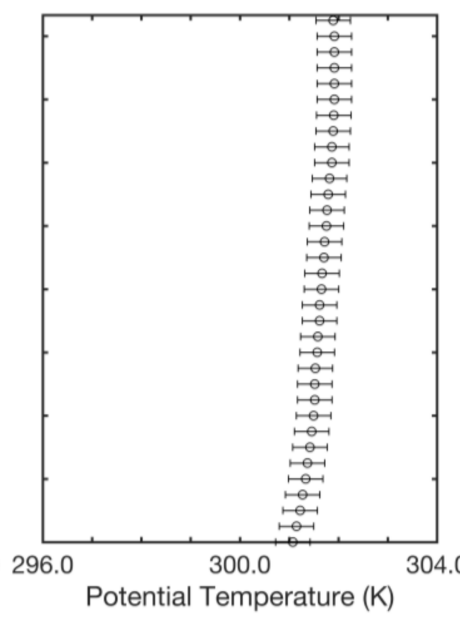

(b)

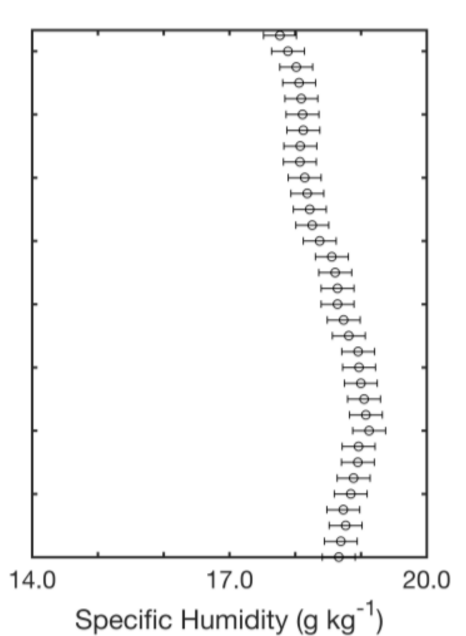

(c)

Figure 2. Vertical profiles of (a) ozone concentration, (b) potential temperature, and (c) specific humidity from surface to $500 \mathrm{~m}$ on 11 May 2018 at 23:00 (LT) (flight 57). These profiles are representative of case 1 (i.e., a normal, undisturbed, stratified atmosphere), including 23 of the 57 ozone profiles. The height of NBL based on ozone concentration is shown (gray color). The dotted line is the instrumental limit of detection for ozone (3 ppbv). Local time (LT) is $4 \mathrm{~h}$ earlier than coordinated universal time (UTC).

An example of a second dataset representative of many other profiles (28\%) is plotted in Figure 3. In this profile, in a smooth shift, the ozone concentration increased by more than $10 \mathrm{ppbv}$ from surface to $150 \mathrm{~m}$, representing the top of the NBL at $150 \mathrm{~m}$. Inflection points at $150 \mathrm{~m}$ were also clear in the vertical profiles of potential temperature and specific humidity, corroborating the ozone profile. For this smooth linear profile of ozone concentration with ascending altitude, a framework for interpretation can be used for an effective diffusivity through turbulent mixing from a fixed concentration of $0 \mathrm{ppbv}$ at the surface (i.e., dry deposition) to $10 \mathrm{ppbv}$ at $150 \mathrm{~m}$ (i.e., an overlying mixed atmosphere representing a large reservoir of ozone). A model of effective diffusivity results in the smooth variation in the vertical profile of ozone concentration from 0 to $150 \mathrm{~m}$ [60], as observed in Figure 3. Profiles of the type represented in Figure 3 are classified as "case 2" in the analysis herein, representing a turbulently mixing NBL $[12,17]$. 


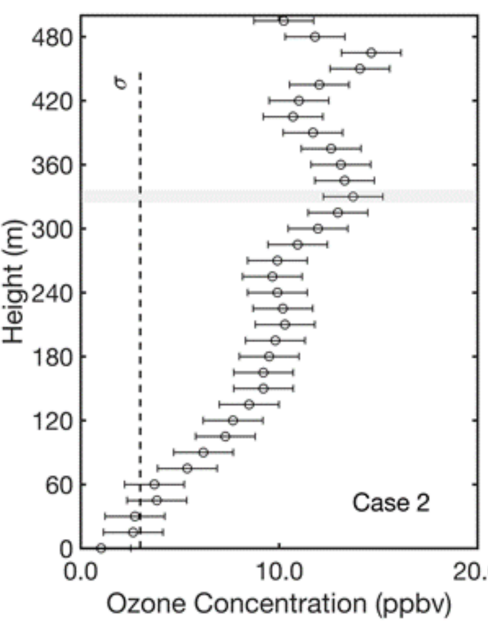

(a)

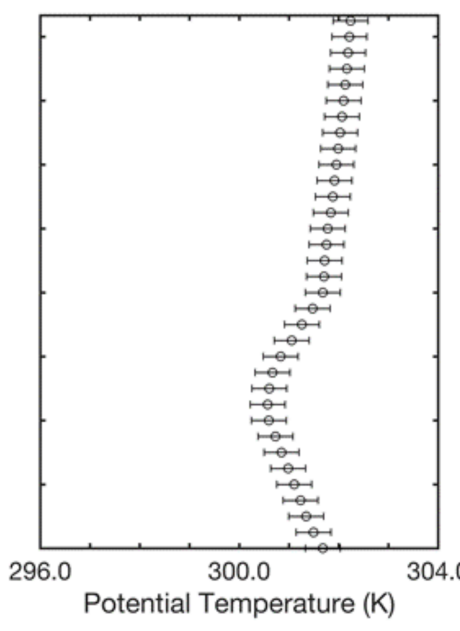

(b)

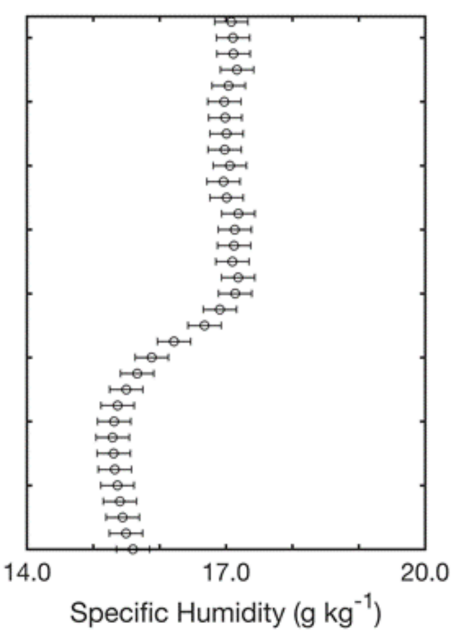

(c)

Figure 3. Vertical profiles of (a) ozone concentration, (b) potential temperature, and (c) specific humidity from surface to $500 \mathrm{~m}$ on 26 April 2018 at 20:30 (LT) (flight 25). These profiles are representative of case 2 (i.e., a turbulently mixing nighttime atmosphere), including 16 of the 57 ozone profiles. The height of NBL based on ozone concentration is shown (gray color). The dotted line is the instrumental limit of detection for ozone ( $3 \mathrm{ppbv}$ ). Local time (LT) is $4 \mathrm{~h}$ earlier than UTC.

Profiles of ozone concentration for cases 1 and 2 of all flights are presented in statistical form in panels (a) and (b) of Figure 4. Horizontal box-whisker statistical plots are shown for selected altitudes from surface to $500 \mathrm{~m}$. Example vertical profiles of ozone concentration for individual flights selected to envelope the statistical representation, as well as go through its center, are also shown.

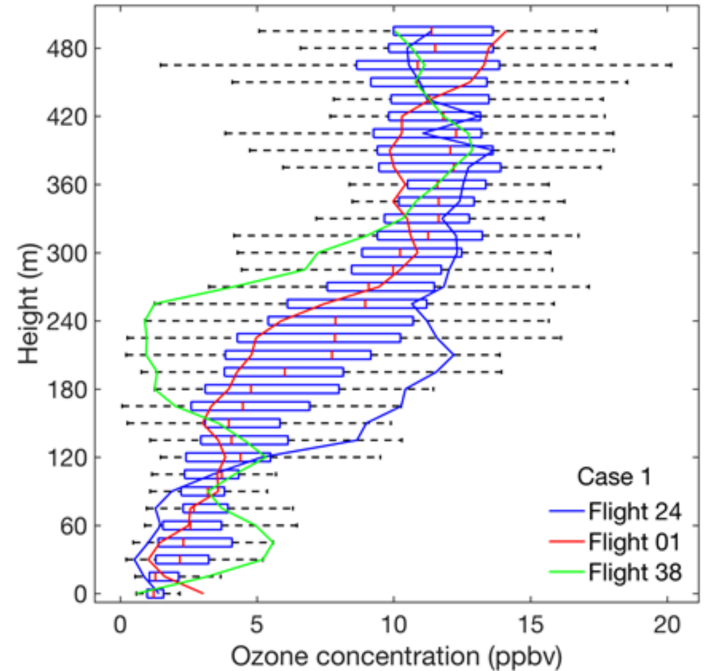

(a)

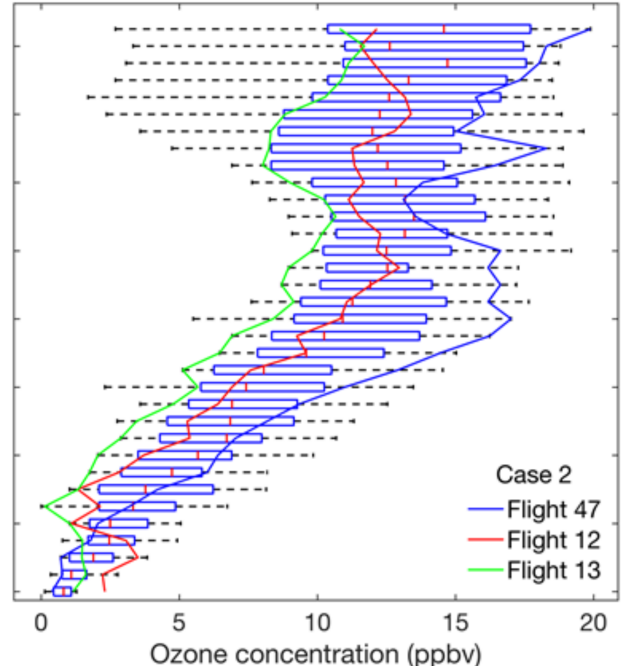

(b)

Figure 4. Vertical profiles of the ozone concentration represented by horizontal box-whisker statistical plots at each altitude for (a) stratified atmospheres of case 1 and (b) turbulent atmospheres (case 2). For each box-whisker plot, the median (red bar) of the combined datasets, quartiles (blue box edges), and the minimum and maximum values (black lines) are represented, excluding outliers. For each panel, three actual vertical profiles of individual flights are selected as examples that envelope the statistical representation.

Figure 4a shows that, for case 1 of a stratified atmosphere, the ozone concentration typically changed by $10 \mathrm{ppbv}$ across the top of the NBL, based on the analysis of individual flights. For case 2 of a turbulent atmosphere, Figure $4 \mathrm{~b}$ shows that the ozone concentration smoothly evolved with altitude 
across the NBL until reaching 10 to $15 \mathrm{ppbv}$, which is characteristic of the overlying atmosphere. Other profiles were more complex with characteristics of both stratified and turbulent atmospheres, and these complex cases were designated as "case 3". Vertical profiles corresponding to case 3 are plotted in Figure S1 (Supplementary Materials).

Statistical results of this study as determined from the vertical profiles of ozone concentration are summarized in Table 1. Overall, cases 1, 2, and 3 corresponded to $40 \%, 28 \%$, and $32 \%$ of the profiles, respectively. The median height for the stratified NBL (i.e., case 1) was $300 \mathrm{~m}$, and the height varied from 230 to $350 \mathrm{~m}$ as quartiles. For the turbulent atmosphere (i.e., case 2), the median height was lower at $290 \mathrm{~m}$, and the quartiles were 255 to $330 \mathrm{~m}$.

Table 1. Count, percentage, and median of nighttime boundary layer (NBL) height, and quartiles of NBL height (25\% and $75 \%$ of distributions) for case classifications for the vertical profiles of ozone concentration in the wet season of 2018. Case 1-normal, undisturbed, stratified atmosphere. Case 2-turbulently mixing atmosphere. Case 3-complex atmosphere characterized by both stratified and turbulent components in the NBL. There is no estimate of NBL height for case 3. N/A-not applicable.

\begin{tabular}{lcccc}
\hline \multicolumn{1}{c}{ Case } & Count $(\boldsymbol{N})$ & Percentage & Median of NBL Height $(\mathbf{m})$ & Quartiles of NBL Height $(\mathbf{m})$ \\
\hline 1: Stratified atmosphere & 23 & $40 \%$ & 300 & 230 and 350 \\
2: Turbulent atmosphere & 16 & $28 \%$ & 290 & 255 and 330 \\
3: Complex atmosphere & 18 & $32 \%$ & N/A & N/A \\
\hline
\end{tabular}

A comparative statistical analysis for the NBL height determined from vertical profiles of ozone concentration, potential temperature, and specific humidity is represented in box-whisker plots in panels (a), (b), and (c) of Figure 5. For case 1, the median NBL heights were 300 m, 352 m, and $300 \mathrm{~m}$ for these three respective tracers. The corresponding values for case 2 were $290 \mathrm{~m}, 260 \mathrm{~m}$, and $280 \mathrm{~m}$. As concluded from Figures 2 and 3, a better estimate of the NBL height was obtained from the ozone profiles than from the temperature or humidity profiles, at least for this study environment. There was a limitation of the meteorological proxies, which were normally used to identify the height of the boundary layer in other studies and planetary locations, in the setting of the tropical forest because of strong evapotranspiration [29], leading to insignificant differences in temperature and humidity in some profiles between the surface and the top of the NBL. By comparison, the ozone concentration was a reliable tracer to probe the NBL height in 100\% of the profiles for cases 1 and 2, representing 39 profiles in total. A chemical proxy like ozone has a strong advantage in the same setting of a tropical forest because of the surface sinks with forest vegetation under background conditions, as well as further chemical losses in polluted environments. For these several different reasons, the implication of Figure 5 is that the median NBL height estimated by potential temperature had biases of $+52 \mathrm{~m}$ for case 1 and $0 \mathrm{~m}$ for case 2, compared to retrieval of the NBL height according to ozone concentration. Correspondingly, the median NBL height estimated by specific humidity had respective biases of $-30 \mathrm{~m}$ and $-10 \mathrm{~m}$ for cases 1 and 2 .

Between cases 1 and 2, no statistically robust differences at the top of the NBL were found for ozone concentration, potential temperature, or specific humidity (Figure S2, Supplementary Materials). This result might be expected because the values at the top of the NBL should correspond to the overlying atmosphere and, thus, might not be specifically related to the different case 1 and case 2 structures of the underlying NBL. Segregation of the datasets by hour from 20:00 to 00:00 (LT) also showed no trend (Table S2 and Figure S3, Supplementary Materials), again as might be expected because the NBL rapidly develops after sunset at approximately 18:00. An analysis to test the association between predominant wind direction at the surface and the observed cases of stratified, turbulent, and complex atmospheres was inconclusive, which can be explained in part because of the weak nighttime surface winds $\left(<1 \mathrm{~m} \cdot \mathrm{s}^{-1}\right)$. 


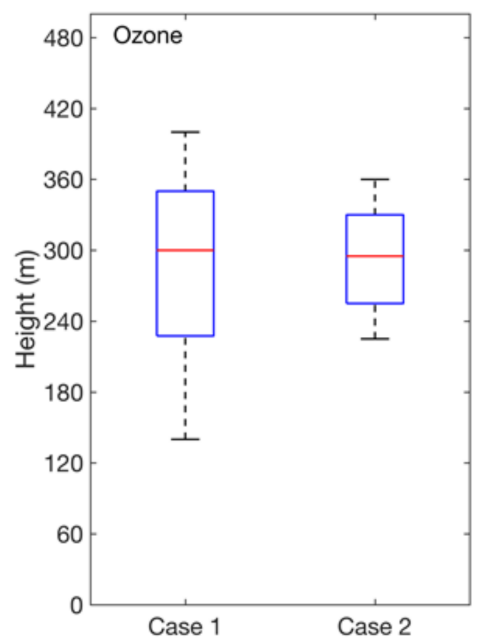

(a)

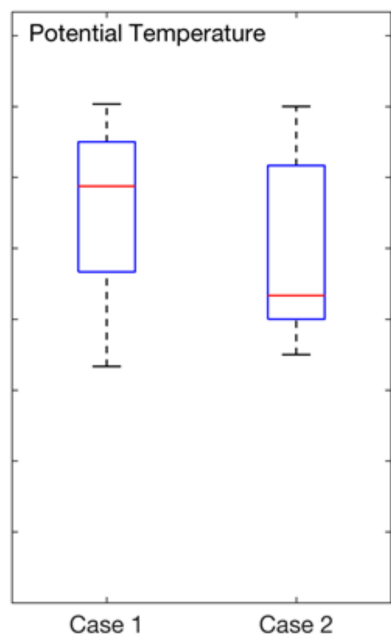

(b)

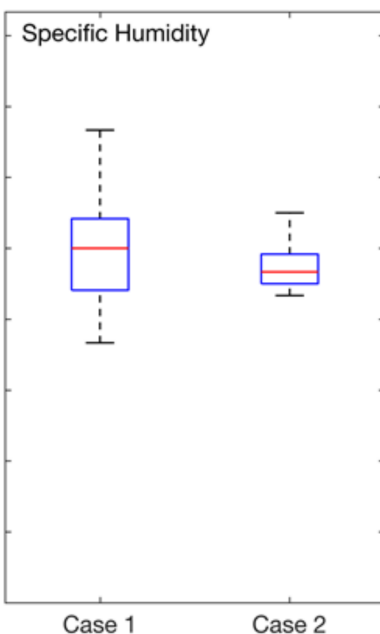

(c)

Figure 5. Box-whisker statistics plots of the height of the NBL during the wet season of 2018 based on (a) ozone concentration, (b) potential temperature, and (c) specific humidity for case 1 of a stratified atmosphere and case 2 of a turbulent atmosphere. Cases 1 and 2 correspond to 23 and 16 ozone profiles, respectively. For each box-whisker plot, the median (red line) of the combined datasets, quartiles (blue box edges), and the minimum and maximum values (black lines) are represented, excluding outliers.

The Cramer's V statistic [61] had a $V$-value of 0.50 and $p$-value of $<0.001$ (Table S3, Supplementary Materials), indicating that the NBL structures strongly correlated with the sky conditions. More specifically, there was a $94 \%$ possibility that a stratified atmosphere occurred when clear skies prevailed, a $41 \%$ possibility of having a turbulent atmosphere under partly cloudy skies, and a $57 \%$ chance for a complex NBL structure when cloudy skies were present. These findings corroborate the stability regimes suggested by Malhi et al. [62], where the first regime is related to clear sky conditions (case 1). This regime corresponds to a stable boundary layer configuration characterized by weak or intermittent turbulence, leading to layer stratification along the vertical profile [62-67] and to a boundary layer top that is well defined by an inflection point in potential temperature [66]. The second atmospheric regime of Malhi et al. is related to partly cloudy or cloudy sky conditions (case 2), which is classified as a weakly stable boundary layer because turbulence tends to be continuous and deep $[55,63,65]$.

The NBL heights observed in this study in an urban region can be compared to earlier studies over rural areas, including forest and pasture surfaces, to explore the influence of the urban island heat effect. Each surface type has distinct differences in energy partitioning, radiation balance, and aerodynamic roughness $[68,69]$. For the study herein over an urban region in the wet season, the quartiles of NBL heights were 230 to $350 \mathrm{~m}$ during time periods of a stratified atmosphere and 255 to $330 \mathrm{~m}$ during time periods of a turbulent atmosphere. Additional statistics are listed in Table 1. Earlier studies focused largely on the dry season [26] or the dry-to-wet transition season [16]. Santos [10], however, carried out measurements in the wet season. Over a forested region, the NBL height varied from 152 to $282 \mathrm{~m}$ between 18:00 and 22:00 (LT). Over a pasture region, the NBL height ranged from 210 to $227 \mathrm{~m}$ between 19:00 and 01:00 (LT). A weakly stable regime was common because of intense convective activity, cloudy skies, and slow surface cooling. Based on case 2 of the present study, an implication could be that the typical NBL over the forest is typically 50 to $100 \mathrm{~m}$ shallower than over the urban region. Over the pasture, the comparison suggests the typical NBL is 45 to $100 \mathrm{~m}$ shallower than over the urban region. For urban areas, in the absence of previous studies in a forested tropical city like Manaus, a comparison can be made to a report for a European city. Dupont et al. [70] reported an NBL height of 300 to $400 \mathrm{~m}$, corroborating the present study. For further comparison, the Global Data Assimilation System [58] estimated the NBL height as 50 to $125 \mathrm{~m}$ at the UAV flight location across the period of study (Table S2, Supplementary Materials), which is several hundred meters below the 
measured NBL heights (Figure S4, Supplementary Materials), highlighting a need to further improve boundary layer representation.

An urban environment has many factors that distinguish it from forested and pasture regions, such as the high heat capacity of building materials, anthropogenic heat sources, the reduction of atmosphere evapotranspiration, and the retention of long-wave radiation due to the increase in atmospheric pollution [71,72]. The combined factors contribute to the urban heat island effect, defined as an increase in surface temperature in urban environments compared the temperature in rural zones. This relatively warmer air over the urban region rises higher, leading to greater vertical development and higher NBL heights and volume compared to pasture and forest regions [73,74]. The increased surface temperature and altered evapotranspiration likewise complicate the use of traditional meteorological tracers (i.e., potential temperature and specific humidity) to estimate NBL height in urban regions.

\section{Conclusions}

In this study, an unmanned aerial vehicle equipped with a chemical sensing system was used to investigate the vertical profiles of nighttime ozone concentration during the wet season in an urban region of central Amazonia. The ozone concentration was observed to increase from the surface layer to the boundary layer top as a result of reactive dry deposition and chemical losses in the surface layer. The height of the nighttime boundary layer was retrieved based on the vertical ozone profiles. Quartiles of the NBL height varied from 255 to $350 \mathrm{~m}$ (see Table 1). These estimates are consistent with results from concurrent measurements of specific humidity and potential temperature. The dataset presented herein and the new findings highlight the possibilities of improved atmospheric measurements made possible by UAVs, as well as the importance of chemical tracers for boundary layer characterization when physical tracers such as specific humidity and potential temperature face challenges, such as over forest regions of high evapotranspiration. The results herein also highlight shortcomings with respect to many models that were developed for nighttime atmospheric chemistry and which do not typically include NBL mixing processes, especially for urban regions.

Supplementary Materials: The following are available online at http://www.mdpi.com/2073-4433/10/10/599/s1: Figure S1: Vertical profiles of ozone concentration, potential temperature, and specific humidity from surface to $500 \mathrm{~m}$. The case classification of each dataset is provided in the inset text. Classifications include (case 1) a normal, undisturbed, stratified nighttime atmosphere based in 23 ozone profiles, (case 2) a turbulently mixing atmosphere based in 16 ozone profiles, and (case 3) a complex atmosphere characterized by both stratified and turbulent components based in 18 ozone profiles. The case classification is discussed in the main text (Section 3). The height of NBL based on ozone concentration is shown (gray color). The dotted line represents the limit of detection for ozone ( $3 \mathrm{ppbv})$. The horizontal bars represent measurement uncertainty. Local time (LT) is $4 \mathrm{~h}$ earlier than UTC. Figure S2: Box-whisker statistics plots of (a) ozone concentration, (b) potential temperature, and (c) specific humidity at the top of the NBL during the wet season of 2018. Results are shown for (case 1) a stratified atmosphere based in 23 ozone profiles and (case 2) a turbulent atmosphere based in 16 ozone profiles. For each box-whisker plot, the median (red line) of the combined datasets, quartiles (blue box edges), and the minimum and maximum values (black lines) are represented, excluding outliers. Figure S3: Vertical profiles of ozone concentration segregated by hour from 20:00 to 00:00 (LT) for the combined dataset of case 1 (i.e., normal stratified atmospheres) based on 23 profiles. Local time (LT) is $4 \mathrm{~h}$ earlier than UTC. Figure S4: Boundary layer heights segregated by hour from 20:00 to 00:00 (LT) as (blue color) determined by the UAV measurements of this study and as (green color) reported for the Global Data Assimilation System. [58] Local time (LT) is $4 \mathrm{~h}$ earlier than UTC. Figure S5: Calibration curve for the POM with calibration factors of $S=1.00$ and $Z=+1$ ppbv applied. Table S1: Summary of studies of the NBL in Amazonia, usually between 18:00 and 00:00 LT. Table S2: Summary of flights and the estimated NBL heights for the period from 19 March 2018 to 11 May 2018 at $3.0918^{\circ} \mathrm{S}$ and $60.0175^{\circ} \mathrm{W}$ in the urban area of Manaus. Local time (LT) is $4 \mathrm{~h}$ earlier than UTC. Wind and wind velocity are from a weather station at ground level. The estimated NBL heights are based on profile cases 1 or 2 (see main text). "N/A" denotes that no estimate was made. The NBL height is also estimated by the Global Data Assimilation System 51 applied to the UAV flight location. The system stability classification is also listed. Table S3: Results of Cramer's V analysis for the association between the structures of the observed profiles (i.e., cases 1, 2, and 3) and sky conditions (i.e., clear, partly cloudy, and cloudy). Table S4: Comparison of data collection characteristics of radiosondes, tethered balloons, and copter unmanned aerial vehicles (UAVs) for typical measurements of potential temperature, specific humidity, and ozone. For comparison purposes, the height between readings, the number of data points, and the time period to collect data correspond to an altitude profile from 0 to $500 \mathrm{~m}$. The UAV 
characteristics are for the operational conditions of this study. The characteristics of radiosondes and tethered balloons are adapted from Balsley et al. [75].

Author Contributions: Conceptualization, S.T.M., P.G., and R.S.; methodology, P.G. and J.Y.; software, P.G., A.M., and R.B.; validation, S.T.M. and P.G.; formal analysis, P.G.; investigation, P.G., C.B., R.B., and I.R.; resources, S.T.M., R.S., and P.G.; data curation, P.G.; writing-original draft preparation, P.G., A.M., I.R., and C.B.; writing-review and editing, P.G., J.Y., and S.T.M.; visualization, P.G. and J.Y.; supervision, S.T.M. and R.S.; project administration, P.G.; funding acquisition, S.T.M. and R.S.

Funding: This research was funded by the Brazilian Federal Agency for Support and Evaluation of Graduate Education (CAPES), grant number 88881.187481/2018-01, the Brazilian National Council for Scientific and Technological Development (CNPq), grant number 142166/2015-4, the Amazonas State Research Foundation (FAPEAM) (Senior Visiting International Researcher), grant numbers 062.00568/2014 and 062.00491/2016), the Harvard Climate Change Solutions Fund, the Harvard David Rockefeller Center for Latin American Studies (DRCLAS), the Postdoctoral Program in Environmental Chemistry of the Dreyfus Foundation, and the Division of Atmospheric and Geospace Sciences of the USA National Science Foundation, grant number AGS-1829025.

Acknowledgments: The Brazilian Air Force, through the Department of Airspace Control (DECEA) and the National Civil Aviation Agency (ANAC), is acknowledged for the authorizations of flights and support during the scientific experiment.

Conflicts of Interest: The funders had no role in the design of the study, in the collection, analyses, or interpretation of data, in the writing of the manuscript, or in the decision to publish the results.

\section{References and Note}

1. Stull, R.B. An Introduction to Boundary Layer Meteorology; Kluwer Academic Publishers: Dordrecht, The Netherlands, 1988.

2. Freire, L.S.; Gerken, T.; Ruiz-Plancarte, J.; Wei, D.; Fuentes, J.D.; Katul, G.G.; Dias, N.L.; Acevedo, O.C.; Chamecki, M. Turbulent mixing and removal of ozone within an Amazon rainforest canopy. J. Geophys. Res. Atmos. 2017, 122, 2791-2811. [CrossRef]

3. Steeneveld, G.-J.; Nappo, C.J.; Holtslag, A.A. Estimation of orographically induced wave drag in the stable boundary layer during the CASES-99 experimental campaign. Acta Geophys. 2009, 57, 857-881. [CrossRef]

4. Newsom, R.K.; Banta, R.M. Shear-flow instability in the stable nocturnal boundary layer as observed by Doppler lidar during CASES-99. J. Atmos. Sci. 2003, 60, 16-33. [CrossRef]

5. Zilitinkevich, S.S.; Esau, I.N. The effect of baroclinicity on the equilibrium depth of neutral and stable planetary boundary layers. Q. J. Royal Meteorol. Soc. 2003, 129, 3339-3356. [CrossRef]

6. Aneja, V.P.; Adams, A.A.; Arya, S.P. An observational based analysis of ozone trends and production for urban areas in North Carolina. Chemosphere Global Chang. Sci. 2000, 2, 157-165. [CrossRef]

7. Corsmeier, U.; Kalthoff, N.; Kolle, O.; Kotzian, M.; Fiedler, F. Ozone concentration jump in the stable nocturnal boundary layer during a LLJ-event. Atmos. Environ. 1997, 31, 1977-1989. [CrossRef]

8. Salmond, J.A.; McKendry, I.G. Secondary ozone maxima in a very stable nocturnal boundary layer: observations from the Lower Fraser Valley, BC. Atmos. Environ. 2002, 36, 5771-5782. [CrossRef]

9. Oke, T. The Heat Island of the Urban Boundary Layer: Characteristics, Causes and Effects; Springer: Dordrecht, The Netherlands, 1995; pp. 81-107.

10. Santos, R.M.N. Study of the Nocturnal Boundary Layer in the Amazon. Ph.D. Thesis, National Institute of Space Research, Sao Jose dos Campos, SP, Brazil, 2005.

11. Mahrt, L.; Heald, R.C.; Lenschow, D.H.; Stankov, B.B.; Troen, I.B. An observational study of the structure of the nocturnal boundary layer. Bound.-Layer Meteorol. 1979, 17, 247-264. [CrossRef]

12. Mahrt, L. Vertical structure and turbulence in the very stable boundary layer. J. Atmos. Sci. 1985, 42, $2333-2349$. [CrossRef]

13. Finnigan, J. A note on wave-turbulence interaction and the possibility of scaling the very stable boundary layer. Bound.-Layer Meteorol. 1999, 90, 529-539. [CrossRef]

14. Sun, J.; Lenschow, D.H.; Burns, S.P.; Banta, R.M.; Newsom, R.K.; Coulter, R.; Frasier, S.; Ince, T.; Nappo, C.; Balsley, B.B. Atmospheric disturbances that generate intermittent turbulence in nocturnal boundary layers. Bound. -Layer Meteorol. 2004, 110, 255-279. [CrossRef] 
15. Yerramilli, A.; Challa, V.S.; Dodla, V.B.R.; Dasari, H.P.; Young, J.H.; Patrick, C.; Baham, J.M.; Hughes, R.L.; Hardy, M.G.; Swanier, S.J. Simulation of surface ozone pollution in the central gulf coast region using WRF/Chem Model: Sensitivity to PBL and Land Surface Physics. Atmos. Pollut. Res. 2010, 3, 55-71. [CrossRef]

16. Neves, T.T.A.T.; Fisch, G. Night limit layer on pasture area in the Amazon. Rev. Bras. Meteorol. 2011, 26, 619-628. [CrossRef]

17. Banta, R.M.; Pichugina, Y.L.; Brewer, W.A. Turbulent velocity-variance profiles in the stable boundary layer generated by a nocturnal low-level jet. J. Atmos. Sci. 2006, 63, 2700-2719. [CrossRef]

18. Duarte, H.F.; Leclerc, M.Y.; Zhang, G. Assessing the shear-sheltering theory applied to low-level jets in the nocturnal stable boundary layer. Theor. Appl. Climatol. 2012, 110, 359-371. [CrossRef]

19. Santana, R.A.S.; Tóta, J.; Santos, R.M.N.; Vale, R.S. Stability and struture of turbulence under the influence of jets of low night levels in the Southwest Amazon. Rev. Bras. Meteorol. 2015, 30, 405-414. [CrossRef]

20. Betts, A.K.; Gatti, L.V.; Cordova, A.M.; Dias, M.A.S.; Fuentes, J.D. Transport of ozone to the surface by convective downdrafts at night. J. Geophys. Res. Atmos. 2002, 107, LBA 13-11-LBA 13-16. [CrossRef]

21. Gerken, T.; Wei, D.; Chase, R.J.; Fuentes, J.D.; Schumacher, C.; Machado, L.A.; Andreoli, R.V.; Chamecki, M.; de Souza, R.A.F.; Freire, L.S. Downward transport of ozone rich air and implications for atmospheric chemistry in the Amazon rainforest. Atmos. Environ. 2016, 124, 64-76. [CrossRef]

22. Hu, X.-M.; Doughty, D.C.; Sanchez, K.J.; Joseph, E.; Fuentes, J.D. Ozone variability in the atmospheric boundary layer in Maryland and its implications for vertical transport model. Atmos. Environ. 2012, 46, 354-364. [CrossRef]

23. Andreae, M.O.; Acevedo, O.C.; Araújo, A.; Artaxo, P.; Barbosa, C.G.G.; Barbosa, H.M.J.; Brito, J.; Carbone, S.; Chi, X.; Cintra, B.B.L. The Amazon Tall Tower Observatory (ATTO): overview of pilot measurements on ecosystem ecology, meteorology, trace gases, and aerosols. Atmos. Chem. Phys. 2015, 15, 10723-10776. [CrossRef]

24. Oliveira, P.E.; Acevedo, O.C.; Sörgel, M.; Tsokankunku, A.; Wolff, S.; Araújo, A.C.; Souza, R.A.; Sá, M.O.; Manzi, A.O.; Andreae, M.O. Nighttime wind and scalar variability within and above an Amazonian canopy. Atmos. Chem. Phys. 2018, 18, 3083-3099. [CrossRef]

25. Seibert, P.; Beyrich, F.; Gryning, S.-E.; Joffre, S.; Rasmussen, A.; Tercier, P. Review and intercomparison of operational methods for the determination of the mixing height. Atmos. Environ. 2000, 34, 1001-1027. [CrossRef]

26. Fisch, G. Amazonian boundary layer: Observations and modeling aspects. Rev. Bras. Geof. 1999, 17, 85-86. [CrossRef]

27. Sugiyama, G.; Nasstrom, J.S. Methods for Determining the Height of the Atmospheric Boundary Layer; Lawrence Livermore National Laboratory: Springfield, VA, USA, 1999; p. 11.

28. Cros, B.; Fontan, J.; Minga, A.; Helas, G.; Nganga, D.; Delmas, R.; Chapuis, A.; Benech, B.; Andreae, M. Vertical profiles of ozone between 0 - 400 meters in and above the African Equatorial Forest. J. Geophys. Res. 1992, 97, 12877-12887. [CrossRef]

29. Maeda, E.E.; Ma, X.; Wagner, F.H.; Kim, H.; Oki, T.; Eamus, D.; Huete, A. Evapotranspiration seasonality across the Amazon Basin. Earth Syst. Dynam 2017, 8, 439-454. [CrossRef]

30. Behrendt, A.; Pal, S.; Aoshima, F.; Bender, M.; Blyth, A.; Corsmeier, U.; Cuesta, J.; Dick, G.; Dorninger, M.; Flamant, C. Observation of convection initiation processes with a suite of state-of-the-art research instruments during COPS IOP 8b. Q. J. Royal Meteorol. Soc. 2011, 137, 81-100. [CrossRef]

31. Pal, S.; Lopez, M.; Schmidt, M.; Ramonet, M.; Gibert, F.; Xueref-Remy, I.; Ciais, P. Investigation of the atmospheric boundary layer depth variability and its impact on the 222Rn concentration at a rural site in France. J. Geophys. Res. Atmos 2015, 120, 623-643. [CrossRef]

32. Gibert, F.; Schmidt, M.; Cuesta, J.; Ciais, P.; Ramonet, M.; Xueref, I.; Larmanou, E.; Flamant, P.H. Retrieval of average $\mathrm{CO} 2$ fluxes by combining in situ $\mathrm{CO} 2$ measurements and backscatter lidar information. J. Geophys. Res. Atmos. 2007, 112, D10301. [CrossRef]

33. Gerbig, C.; Körner, S.; Lin, J. Vertical mixing in atmospheric tracer transport models: error characterization and propagation. Atmos. Chem. Phys. 2008, 8, 591-602. [CrossRef]

34. Chambers, S.; Williams, A.; Crawford, J.; Griffiths, A.D.; Discussions, P. On the use of radon for quantifying the effects of atmospheric stability on urban emissions. Atmos. Chem. Phys. 2014, 14, 1175-1190. [CrossRef] 
35. Janssen, R.; Vilà-Guerau de Arellano, J.; Ganzeveld, L.; Kabat, P.; Jimenez, J.; Farmer, D.; Van Heerwaarden, C.; Mammarella, I. Combined effects of surface conditions, boundary layer dynamics and chemistry on diurnal SOA evolution. Atmos. Chem. Phys. 2012, 12, 6827-6843. [CrossRef]

36. Pal, S.; Lee, T.; Phelps, S.; De Wekker, S.J.S.o.t.T.E. Impact of atmospheric boundary layer depth variability and wind reversal on the diurnal variability of aerosol concentration at a valley site. Sci. Total Environ. 2014, 496, 424-434. [CrossRef] [PubMed]

37. Dang, R.; Yang, Y.; Hu, X.-M.; Wang, Z.; Zhang, S. A Review of Techniques for Diagnosing the Atmospheric Boundary Layer Height (ABLH) Using Aerosol Lidar Data. Remote Sens. 2019, 11, 1590. [CrossRef]

38. BRAZIL. Establish air quality standards and other measures. National Council of Environment (CONAMA). Resolution no. 003/1990 of June 28, 1990.

39. Li, X.; Liu, J.; Mauzerall, D.L.; Emmons, L.K.; Walters, S.; Horowitz, L.W.; Tao, S. Effects of trans-Eurasian transport of air pollutants on surface ozone concentrations over Western China. J. Geophys. Res. Atmos. 2014, 119, 12-338. [CrossRef]

40. Tang, G.; Zhu, X.; Xin, J.; Hu, B.; Song, T.; Sun, Y.; Zhang, J.; Wang, L.; Cheng, M.; Chao, N. Modelling study of boundary-layer ozone over northern China-Part I: Ozone budget in summer. Atmos. Res. 2017, 187, 128-137. [CrossRef]

41. Chen, P.; Quan, J.; Zhang, Q.; Tie, X.; Gao, Y.; Li, X.; Huang, M. Measurements of vertical and horizontal distributions of ozone over Beijing from 2007 to 2010. Atmos. Environ. 2013, 74, 37-44. [CrossRef]

42. Wei, D.; Ruiz-Plancarte, J.; Freire, L.S.; Gerken, T.; Chamecki, M.; Fuentes, J.D.; Stoy, P.C.; Trowbridge, A.M.; dos Santos, R.M.N.; Acevedo, O. Relationship between canopy turbulence and vertical distribution of reactive gases in the central Amazon rainforest. Ciência e Natura 2016, 38, 543-547. [CrossRef]

43. Fares, S.; McKay, M.; Holzinger, R.; Goldstein, A.H.; Meteorology, F. Ozone fluxes in a Pinus ponderosa ecosystem are dominated by non-stomatal processes: Evidence from long-term continuous measurements. Agric. For. Meteorol. 2010, 150, 420-431. [CrossRef]

44. Fares, S.; Loreto, F.; Kleist, E.; Wildt, J. Stomatal uptake and stomatal deposition of ozone in isoprene and monoterpene emitting plants. Plant Biol. 2007, 9, 44-54. [CrossRef]

45. Schaub, M.; Skelly, J.; Zhang, J.; Ferdinand, J.A.; Savage, J.E.; Stevenson, R.; Davis, D.D.; Steiner, K.C. Physiological and foliar symptom response in the crowns of Prunus serotina, Fraxinus americana and Acer rubrum canopy trees to ambient ozone under forest conditions. Environ. Pollut. 2005, 133, 553-567. [CrossRef]

46. Karnosky, D.; Pregitzer, K.S.; Zak, D.R.; Kubiske, M.E.; Hendrey, G.; Weinstein, D.; Nosal, M.; Percy, K.J.P. Scaling ozone responses of forest trees to the ecosystem level in a changing climate. Plant Cell Environ. 2005, 28, 965-981. [CrossRef]

47. Tjoelker, M.; Luxmoore, R.J.N.P. Soil nitrogen and chronic ozone stress influence physiology, growth and nutrient status of Pinus taeda L. and Liriodendron tulipifera L. seedlings. New Phytol. 1991, 119, 69-81. [CrossRef]

48. Kurpius, M.R.; Goldstein, A.H. Gas-phase chemistry dominates O3 loss to a forest, implying a source of aerosols and hydroxyl radicals to the atmosphere. Geophys. Res. Lett. 2003, 30, 24. [CrossRef]

49. Wieser, G.; Häsler, R.; Götz, B.; Koch, W.; Havranek, W.J.E.P. Role of climate, crown position, tree age and altitude in calculated ozone flux into needles of Picea abies and Pinus cembra: a synthesis. Environ. Pollut. 2000, 109, 415-422. [CrossRef]

50. Paoletti, E.; De Marco, A.; Beddows, D.C.; Harrison, R.M.; Manning, W.J. Ozone levels in European and USA cities are increasing more than at rural sites, while peak values are decreasing. Environ. Pollut. 2014, 192, 295-299. [CrossRef]

51. Sicard, P.; De Marco, A.; Troussier, F.; Renou, C.; Vas, N.; Paoletti, E.J.A.E. Decrease in surface ozone concentrations at Mediterranean remote sites and increase in the cities. Atmos. Environ. 2013, 79, 705-715. [CrossRef]

52. IBGE. Brazilian Institute of Geography and Statistics. Available online: https:/cidades.ibge.gov.br/brasil/am/ manaus/panorama (accessed on 20 June 2019).

53. BRAZIL. National Institute of Meteorology. Available online: http://www.inmet.gov.br/portal/index.php?r= clima/normaisClimatologicas (accessed on 5 September 2019).

54. ANAC. National Civil Aviation Agency. Available online: http://www.anac.gov.br/assuntos/legislacao/ legislacao-1/rbha-e-rbac/rbac/rbac-e-94-emd-00 (accessed on 2 July 2019). 
55. Santos, R.M.N.; Fisch, G.; Dolman, A.; Waterloo, M. Modeling of the Night Limit Layer (CLN) during the wet season in the Amazon under different development conditions. Rev. Bras. Meteorol. 2007, 22, 387-407. [CrossRef]

56. Choi, W.; Faloona, I.; McKay, M.; Goldstein, A.; Baker, B.J.A.C. Estimating the atmospheric boundary layer height over sloped, forested terrain from surface spectral analysis during BEARPEX. Atmos. Chem. Phys. 2011, 11, 6837-6853. [CrossRef]

57. Liebetrau, A.M. Measures of Association; Sage: Newbury Park, CA, USA, 1983; Volume 32.

58. Rolph, G.; Stein, A.; Stunder, B. Real-time environmental applications and display sYstem: READY. Environ. Model. Softw 2017, 95, 210-228. [CrossRef]

59. NOAA (National Oceanic and Atmospheric Administration). Global Data Assimilation System (GDAS). Available online: https://www.ncdc.noaa.gov/data-access/model-data/model-datasets/global-dataassimilation-system-gdas (accessed on 6 August 2019).

60. Kim, J.; Mahrt, L.J.T.A. Simple formulation of turbulent mixing in the stable free atmosphere and nocturnal boundary layer. Tellus A 1992, 44, 381-394. [CrossRef]

61. Cramér, H. Mathematical Methods of Statistics; Princeton University Press: Uppsala, Sweden, 1999 ; Volume 9.

62. Malhi, Y.S.J.B.-L.M. The significance of the dual solutions for heat fluxes measured by the temperature fluctuation method in stable conditions. Bound. -Layer Meteorol. 1995, 74, 389-396. [CrossRef]

63. Lenschow, D.H.; Li, X.S.; Zhu, C.J.; Stankov, B.B. The stably stratified boundary layer over the Great Plains. Bound. Layer Meteorol. 1988, 95-121. [CrossRef]

64. Mahrt, L.; Sun, J.; Blumen, W.; Delany, T.; Oncley, S. Nocturnal Boundary-Layer Regimes. Bound. -Layer Meteorol. 1998, 88, 255-278. [CrossRef]

65. Ohya, Y.; Neff, D.E.; Meroney, R.N. Turbulence structure in a stratified boundary layer under stable conditions. Bound. -Layer Meteorol. 1997, 83, 139-162. [CrossRef]

66. Smedman, A.-S. Observations of a multi-level turbulence structure in a very stable atmospheric boundary layer. Bound. -Layer Meteorol. 1988, 44, 231-253. [CrossRef]

67. Tombrou, M.; Founda, D.; Boucouvala, D. Nocturnal boundary layer height prediction from surface routine meteorological data. Meteorl. Atmos. Phys. 1998, 68, 177-186. [CrossRef]

68. Betts, A.; Fisch, G.; Von Randow, C.; Silva Dias, M.; Cohen, J.; Da Silva, R.; Fitzjarrald, D. The Amazonian boundary layer and mesoscale circulations. In Amazonia and Global Change; American Geophysical Union: Washington, DC, USA, 2009. [CrossRef]

69. Fisch, G.; Tota, J.; Machado, L.; Dias, M.S.; Lyra, R.d.F.; Nobre, C.; Dolman, A.; Gash, J. The convective boundary layer over pasture and forest in Amazonia. Theor. Appl. Climatol 2004, 78, 47-59. [CrossRef]

70. Dupont, E.; Menut, L.; Carissimo, B.; Pelon, J.; Flamant, P.J.A.E. Comparison between the atmospheric boundary layer in Paris and its rural suburbs during the ECLAP experiment. Atmos. Environ. 1999, 33, 979-994. [CrossRef]

71. Souza, D.O.; Alvalá, R.C.S. Observational evidence of the urban heat island of Manaus City, Brazil. Meteorol. Appl. 2014, 21, 186-193. [CrossRef]

72. Arya, P.S. Introduction to Micrometeorology; Academic Press: San Diego, CA, USA, 2001; Volume 79.

73. Soltani, A.; Sharifi, E. Daily variation of urban heat island effect and its correlations to urban greenery: A case study of Adelaide. Front. Archit. Res. 2017, 6, 529-538. [CrossRef]

74. Oke, T.R. The urban energy balance. Prog. Phys. Geogr. 1988, 12, 471-508. [CrossRef]

75. Balsley, B.B.; Jensen, M.L.; Frehlich, R.G. The use of state-of-the-art kites for profiling the lower atmosphere. Bound. -Layer Meteorol. 1998, 87, 1-25. [CrossRef]

(C) 2019 by the authors. Licensee MDPI, Basel, Switzerland. This article is an open access article distributed under the terms and conditions of the Creative Commons Attribution (CC BY) license (http://creativecommons.org/licenses/by/4.0/). 